\title{
Multiple site-directed mutagenesis via simple cloning by prolonged overlap extension
}

Rasmus Hejlesen ${ }^{1}$ (D) \& Ernst-Martin Füchtbauer*,1 (iD)

${ }^{1}$ Department of Molecular Biology \& Genetics, Aarhus University, C.F. Møllers Allé 3, 8000 Aarhus C, Denmark; *Author for correspondence: emf@mbg.au.dk

BioTechniques 68: 345-348 (June 2020) 10.2144/btn-2019-0104

First draft submitted: 13 August 2019; Accepted for publication: 24 January 2020; Published online: 6 May 2020

\section{ABSTRACT}

We describe the application of simple cloning by prolonged overlap extension for multiple site-directed mutagenesis in the same plasmid. We show that it is possible to use this technique with very short PCR templates. The technique is ideally suited for the generation of longer donor DNA sequences for CRISPR/Cas9-mediated homologous repair.

\section{METHOD SUMMARY}

Simple cloning by prolonged overlap extension utilizes overlapping PCR fragments to create large repetitive multimers, which can be used to directly transform bacteria. Internal circularization of these long concatemers generates the desired plasmid.

\section{KEYWORDS:}

donor template generation • gene editing • multiple site-directed mutagenesis • prolonged overlap extension • seamless cloning • seamless plasmid assembly

Classic subcloning in plasmids uses restriction enzymes and ligases. However, a method known as 'simple cloning' using direct transformation of a prolonged overlap extension (POE) PCR product has been used to generate seamless subcloning [1]. Overlapping PCR products are joined into long repetitive multimers by POE-PCR and directly transformed into bacteria, which circularize them into plasmids. This technique has been used for applications as different as large-size random gene mutagenesis [2], assembly of up to four fragments in a single reaction [3] and multi-site saturation mutagenesis [4].

Here we show the introduction of three specific mutations into an existing plasmid, utilizing mismatch primers that were assembled in a single reaction (Figure 1), without the need for Dpnl digestion and several rounds of transformation and plasmid isolation, which is required in most commercially available directed mutagenesis kits. We optimized the method for the use of fragments as small as $70 \mathrm{bp}$; the shortest fragments reported previously have been $200 \mathrm{bp}$ [1].

In order to create three mutations in the RelA insert of pBSII-SK-RelA, a combination of primer mutagenesis and simple cloning by POE was used. Insert 1 (I1), insert 2 (I2) and the vector backbone (VB) were generated using the plasmid as template. Each of the three primer sets introduced a one- or two-base-pair mutation by mismatch. A POE-PCR was performed with the three fragments, creating a large multimeric POE-PCR product which was then transformed directly into competent $\mathrm{DH} 5 \alpha$ Escherichia coli with a transformation efficiency (TE) of $1.4 \times 10^{5}$ colony forming units (cfu)/ $\mathrm{Mg}$ POE-PCR product, compared with a TE of $9.18 \times 10^{7} \mathrm{cfu} / \mu \mathrm{g}$ using supercoiled pUC18. All colonies tested by PCR (25/25) showed the expected fragment size for a plasmid containing I1 and I2, while the presence of the functional VB was tested by ampicillin resistance. Sanger sequencing confirmed the predicted sequence, including all mutations, in $3 / 3$ plasmids. The three purified fragments (I1, I2 and VB), the POE-PCR product, Cfr10I-digested POE-PCR product, purified plasmid and the same plasmid digested with Cfr10l were analyzed on a $1 \%(\mathrm{~W} / \mathrm{v})$ agarose gel (Figure 2$)$. The smallest insert size previously reported to be joined by POE was 200 bp [1]. Here we show the joining of an insert of only 70 bp with two other fragments.

We also used POE-PCR to assemble a four-fragment plasmid, in which the shortest fragment was 149 bp. Direct transformation gave a TE of $6 \times 10^{4} \mathrm{cfu} / \mu \mathrm{g}$ POE-PCR product with 22/66 colonies (33\%) tested by PCR showing the expected fragment sizes for a plasmid containing the three inserts. Sanger sequencing confirmed the presence of all four fragments in $3 / 3$ plasmids, although two of these plasmids carried a duplication of the VB.

Different approaches for mutagenesis have been described. Most commercial site-directed mutagenesis kits introduce mutations by amplifying entire plasmids using mismatch primers. The mutagenized PCR product can be isolated because it escapes the methylationsensitive Dpnl restriction digest that removes the original plasmid [5]. To introduce three mutations, this method requires three rounds of mutagenesis followed by transformation and plasmid isolation, making this approach time-consuming and expensive.

In contrast, simple cloning by POE only needs relatively short (in our case 26-33 bases) oligonucleotides as PCR primers and a high-fidelity polymerase, making it a simple and inexpensive alternative. 
(A)
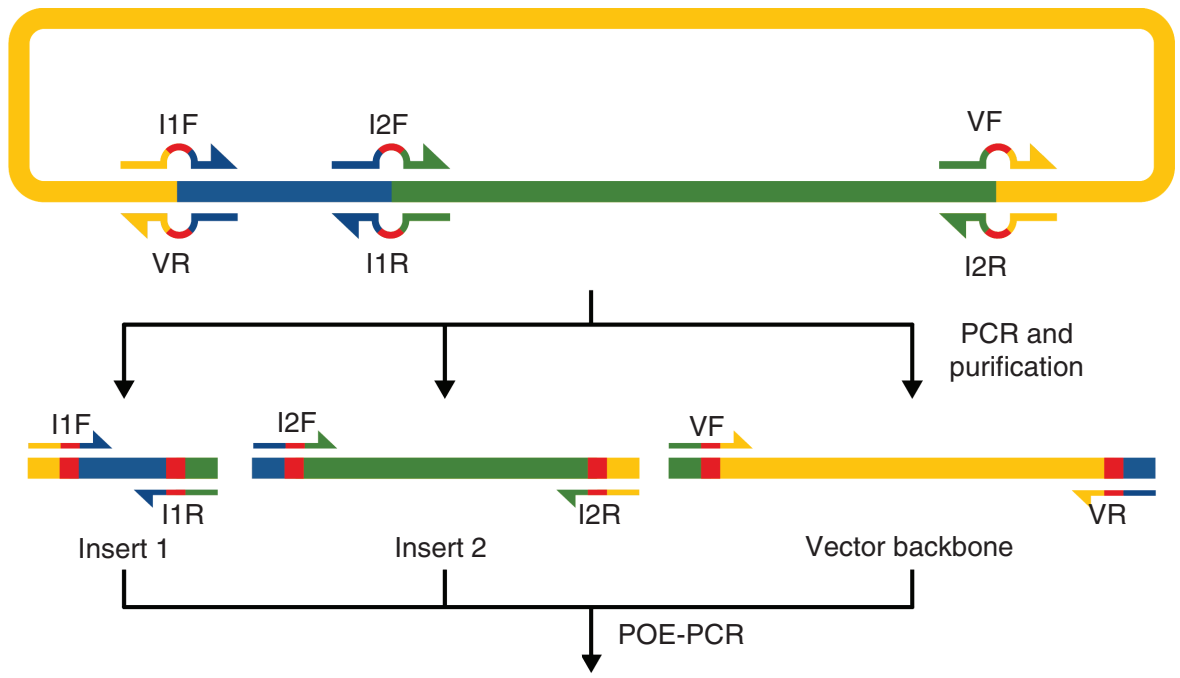

(C)

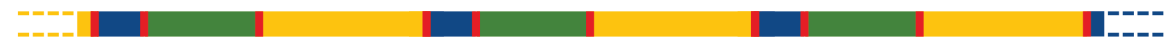

(D)

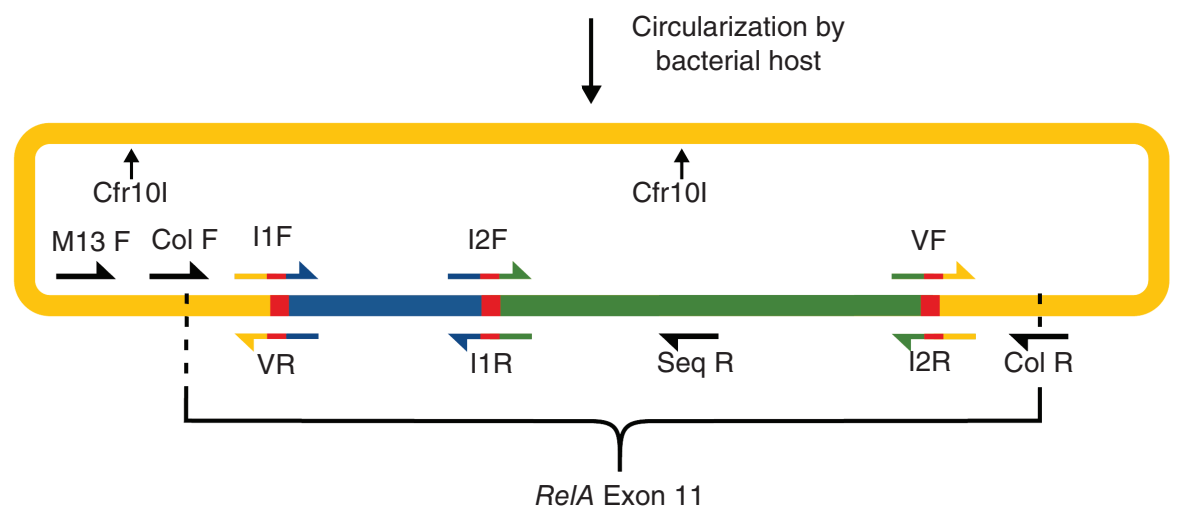

Figure 1. Multiple site-directed mutagenesis using simple cloning by prolonged overlap extension and mismatch primers. (A) The template, in this case a plasmid carrying a gene of interest, but possibly also individual DNA fragments, is used for PCR amplification with mismatch primers creating overlapping regions between the amplicons. Yellow, green and blue sections represent the three amplicons; the mismatches introducing mutations are red. (B) The three PCR products are purified; POE-PCR extends the products, creating long repetitive multimers. (C) The multimeric POE-PCR product is directly transformed into a bacterial host, where it is circularized. (D) The mutagenized plasmid is then purified from the bacterial host. Black arrows indicate the position of the sequencing primers used; the stippled lines mark the borders of the gene of interest. The two Cfr10l restriction sites were used for diagnostic digestion.

For primer nomenclature and sequences, see Table 1.

Both fragment generation and POE-PCR rely on 25-30 replication cycles. Before transformation, each DNA fragment will be amplified by 50-60 PCR cycles, which bears the risk of PCR-generated mutations. For a single site-directed mutagenesis a classical approach would require fewer PCR cycles. However, multiple mutagenesis steps will require a comparable number of (or more) PCR cycles. A highfidelity polymerase should be used for POE-PCR to avoid undesired mutations. After unsuccessful attempts using the Pfu Polymerase (Thermo Scientific, MA, USA) for POE-PCR, we recommend using the Phusion polymerase, as supported by other literature describing the method $[1,4,6,7]$. We found very few PCR-generated mutations; however, in some cases, duplication of the VB was observed, suggesting that recombination in the transformed bacteria might result in unexpected events.

Protocols describing simple cloning by POE differ in their quantitative calculations for the POE-PCR. Some use $2 \mathrm{ng} / \mu \mathrm{l}$ of insert DNA fragment and an equimolar amount of VB [1,4], while others use 4-5 ng/ $\mu \mathrm{l}$ VB DNA fragment and an equimolar amount of insert $[6,7]$. In the first approach, the length of the insert determines the total amount of PCR template and possibly the POE product which, in the second approach, depends on the length of the vector. It would appear more logical to mix the fragments in equimolar amounts by a defined molarity independent of VB and insert size. Using this approach, the POE-PCR reaction and the transformation could be optimized for the molarity of those fragments yielding the highest TE (as long as the total DNA concentration stayed below the product inhibition threshold of the given polymerase). 


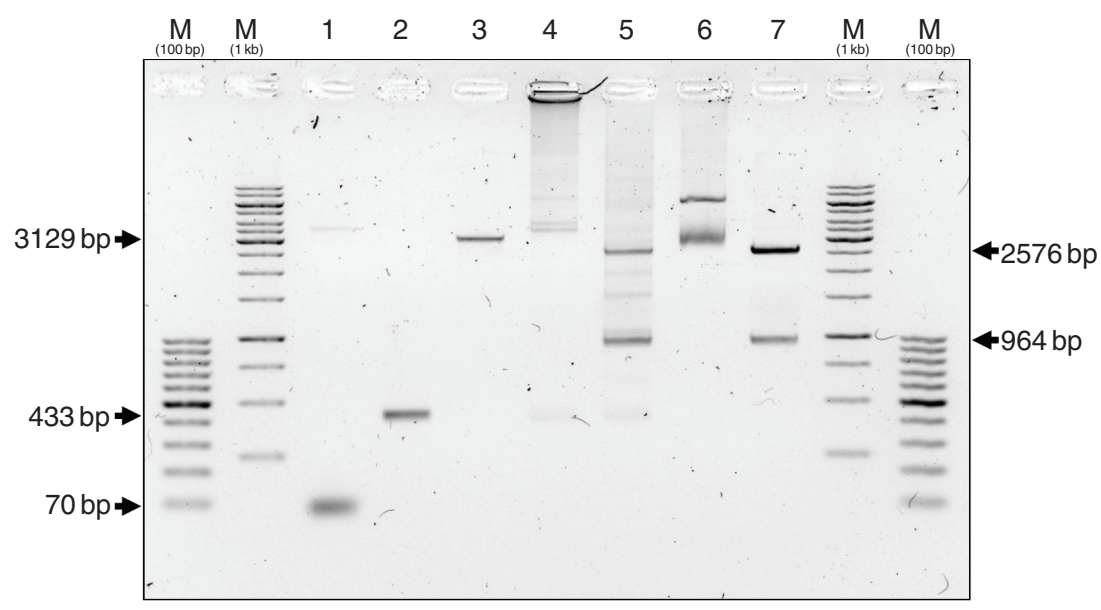

Figure 2. Agarose gel of PCR products and plasmid. M (100 bp): GeneRuler 100-bp DNA ladder. M (1 kb): GeneRuler 1-kb DNA ladder. Lanes 1-3: PCR products using pBSII-SK-RelA as template. 1: Insert 1, expected size $70 \mathrm{bp}$. The weak band at about $3.7 \mathrm{~kb}$ results from PCR amplification of the template plasmid. 2: Insert 2, expected size 433 bp. 3: The plasmid backbone, expected size 3129 bp. Lane 4: Prolonged overlap extension (POE)-PCR product. Note that the majority of the product is trapped in the slot due to its large size. Smear and lower bands most likely represent concatemers of different sizes. Lane 5: POE-PCR product digested with Cfr10l, a double cutter, which is expected to result in fragments of $2576 \mathrm{bp}$ and $964 \mathrm{bp}$. Lanes 6 and 7: Analysis of the POE-generated plasmid. 6: Undigested. 7: Digested with Cfr10I.

\begin{tabular}{|c|c|c|c|}
\hline Primer name & Sequence $\left(5^{\prime}-3^{\prime}\right)$ & $\mathrm{T}_{\mathrm{m}}\left({ }^{\circ} \mathrm{C}\right)$ & GC\% \\
\hline VR (Vector backbone reverse) & CCTCGGGGCTTCCCAACGGTCTCTCAGGAGATG & 69.1 & 63.6 \\
\hline VF (Vector backbone forward) & GTGCCAAGGCCAGGGCITGGTTTGAGATCTGCC & 69.4 & 60.6 \\
\hline I2R (Insert 2 reverse) & GGCAGATCTCAAACCAAGCCCTGGCCTTGGCAC & 69.4 & 60.6 \\
\hline I2F (Insert 2 forward) & GTGGGAGCTGGGCTAGGGGGCCTCTG & 70.0 & 73.1 \\
\hline IIR (Insert 1 reverse) & CAGAGGCCCCCTAGCCCAGCTCCCAC & 70.0 & 73.1 \\
\hline I1F (Insert 1 forward) & СATCTCCTGAGAGACCGTTGGGAAGCCCCGAGG & 69.1 & 63.6 \\
\hline M13 forward & GTAAAACGACGGCCAG & 50.7 & 56.2 \\
\hline Sequencing reverse & СACCTGTTCCAAAGAGCACC & 56.3 & 55 \\
\hline Colony forward & AGCGCGCGTAATACGACTCACTATAGGTCGCTGTCAGCACCTTAG & 69.0 & 53.3 \\
\hline Colony reverse & CTGCAGGAATTCGATATCAAGCTTACCTACACCTTCCCAGCATC & 66.2 & 47.7 \\
\hline
\end{tabular}

Introduced mutations are bold/underlined. In the colony PCR primers, the insert-specific sequence is underlined. These primers are unnecessarily long but were available from the original cloning of the gene of interest into the PBSII-SK vector.

GC\%: GC content; $T_{m}$ : Theoretical primer melting temperature.

POE-PCR has previously been described to join fragments as small as $200 \mathrm{bp}$ [1]. In our experiment, one of the three fragments was only $70 \mathrm{bp}$ long, and the POE-PCR was first successful when high concentrations of fragments were added. A concentration of $8 \mathrm{ng} / \mu \mathrm{l}$ VB was needed, while the concentration originally recommended was $4-5 \mathrm{ng} / \mu \mathrm{l}^{-1}[6,7]$. This shows that it is possible to join small fragments, but the actual reaction conditions might need to be adjusted if the fragment sizes vary considerably.

A possible application of this method is the generation of long donor DNA sequences for CRISPR/Cas 9 mutagenesis. If the backbone plasmid contains an RNA polymerase promoter (e.g., T7) a single-strand donor for EasiCRISPR can easily be generated [8]. This is done by synthesizing RNA from the T7 promoter, followed by reverse transcription of the RNA.

Primers were designed with a 26- to 33-nucleotide overlap as described previously $[1,4]$. Each primer also contained a mutation that was flanked by the overlap. As much as possible, primers were designed with a GC content between 40 and $60 \%$ and a $T_{m}$ of $65 \pm 5^{\circ} \mathrm{C}$ (Table 1).

All fragments were amplified using Phusion high-fidelity DNA polymerase (Thermo Scientific \#F530S) following the manufacturer's protocol. pBSII-SK-RelA, a modified version of the pBSII-SK (Stratagene) carrying most of exon 11 of the murine RelA, was used as template. I1 (70 bp) and I2 (433 bp) were amplified in a total reaction volume of $50 \mu$ using primer pairs I1F/I1R and I2F/I2R, respectively, with the following program: $1 \times 98^{\circ} \mathrm{C}$ for $30 \mathrm{~s} ; 25$ cycles of $10 \mathrm{~s}$ at $98^{\circ} \mathrm{C}, 30 \mathrm{~s}$ at $64^{\circ} \mathrm{C}, 30 \mathrm{~s}$ at $72^{\circ} \mathrm{C}$; and a final elongation of 10 min at $72^{\circ} \mathrm{C}$. The VB $(3 \mathrm{~kb})$ was amplified in a total reaction volume of $100 \mu \mathrm{l}$ with primers VF and VR (forward and reverse) using the following program: $1 \times 98^{\circ} \mathrm{C}$ for $30 \mathrm{~s} ; 25$ cycles of $10 \mathrm{~s}$ at $98^{\circ} \mathrm{C}, 1 \mathrm{~min} 30 \mathrm{~s}$ at $64^{\circ} \mathrm{C}, 30 \mathrm{~s}$ at $72^{\circ} \mathrm{C}$; and a final elongation of $10 \mathrm{~min}$ at $72^{\circ} \mathrm{C}$. 11 and $\mathrm{I} 2$ 
were purified using a GeneJet PCR Purification Kit (Thermo Scientific \#K0702), and the VB was purified from 1\% (w/v) agarose gel using the GeneJET Gel Extraction Kit (Thermo Scientific \#K0691); yields were 0.4, 1.5 and $1.4 \mu \mathrm{g}$, respectively.

POE-PCR was performed in $25 \mu \mathrm{l} 1 \times$ Green HF buffer containing $4 \mathrm{nM}(8 \mathrm{ng} / \mu \mathrm{l})$ purified plasmid backbone, equimolar amounts of 11 and I2, $0.2 \mathrm{mM}$ dNTP and $1.25 \mathrm{U}$ Phusion, with the following program: $1 \times 98^{\circ} \mathrm{C}$ for $30 \mathrm{~s} ; 30$ cycles of $10 \mathrm{~s}$ at $98^{\circ} \mathrm{C}, 15 \mathrm{~s}$ at $60^{\circ} \mathrm{C}, 2 \mathrm{~min} 42 \mathrm{~s}$ at $72^{\circ} \mathrm{C}$; and a final elongation of $10 \mathrm{~min}$ at $72^{\circ} \mathrm{C}$.

The $5 \mu \mathrm{l}$ of the POE-PCR product, $20 \mu \mathrm{l} 5 \times \mathrm{KCM}$ buffer and $75 \mu \mathrm{l} \mathrm{H} \mathrm{H}_{2} \mathrm{O}$ were precooled on ice for $2 \mathrm{~min}$. The $100 \mu \mathrm{l}$ were mixed with $10^{8}-10^{9}$ competent $\mathrm{DH} 5 \alpha \mathrm{E}$. coli bacteria and put on ice for $20 \mathrm{~min}$. Heat shock was carried out for 10 min at room temperature. Bacteria recovered in LB medium without antibiotics for 50 min with shaking $(200 \mathrm{rpm})$ at $37^{\circ} \mathrm{C}$. Transformed bacteria were selected overnight on LB-agar plates supplemented with $100 \mu \mathrm{g} / \mathrm{ml}$ ampicillin. Single colonies were grown in $5 \mathrm{ml} \mathrm{LB}$ medium supplemented with $100 \mu \mathrm{g} / \mathrm{ml}$ ampicillin overnight.

Colony PCR was performed using DreamTaq polymerase (ThermoScientific, \#EP0701) in a final volume of $25 \mu \mathrm{l}$. Single colonies were transferred to $50 \mu \mathrm{l}$ of LB medium and $1 \mu \mathrm{l}$ of this was used as template for the PCR, with the Colony Forward and Colony Reverse primers and the following conditions: $1 \times 95^{\circ} \mathrm{C}$ for $5 \mathrm{~min} ; 20$ cycles of $45 \mathrm{~s}$ at $94^{\circ} \mathrm{C}, 1 \mathrm{~min}$ at $61^{\circ} \mathrm{C}$ and $1 \mathrm{~min} 21 \mathrm{~s}$. at $72^{\circ} \mathrm{C}$. Selected positive colonies were Sanger sequenced (Eurofins Genomics) using the M13 Forward and the Sequencing Reverse primers (Table 1). Plasmids and the POE-PCR product were digested with Cfr10I (ThermoScientific, \#FD0184) to verify the correct unit size. All DNA fragments were analyzed on a $1 \%(\mathrm{w} / \mathrm{v})$ agarose gel (Figure 2$)$.

We show that several mutations can be introduced in a plasmid simultaneously using simple cloning by POE, a fast and economic method to assemble different fragments seamlessly into one plasmid. Furthermore, we expanded the range of POE-PCR to an insert size of only $70 \mathrm{bp}$, considerably smaller than the $200 \mathrm{bp}$ reported previously.

There is increasing demand for complex changes in donor DNA templates, used in CRISPR/Cas9-mediated mutagenesis. We believe that multiple site-directed mutagenesis and simple cloning by POE-PCR will be a favorable tool for this application.

\section{Author contributions}

R Hejlesen designed the study, performed the experiments and wrote the manuscript. E-M Füchtbauer designed the study and wrote the manuscript.

\section{Acknowledgments}

The authors thank T Birch for technical assistance, EW Sørensen for help with Figure 1 and CB Eriksen for contributing her data.

\section{Financial \& competing interests disclosure}

This work was supported by a DARE-grant from the DANDRITE program at Aarhus University. The authors have no other relevant affiliations or financial involvement with any organization or entity with a financial interest in or financial conflict with the subject matter or materials discussed in the manuscript apart from those disclosed.

No writing assistance was utilized in the production of this manuscript.

\section{Open access}

This work is licensed under the Attribution-NonCommercial-NoDerivatives 4.0 Unported License. To view a copy of this license, visit http: //creativecommons.org/licenses/by-nc-nd/4.0/

\section{References}

Papers of special note have been highlighted as: $\bullet$ of interest; $\bullet \bullet$ of considerable interest

1. You C, Zhang X-Z, Zhang YHP. Simple cloning via direct transformation of PCR product (DNA Multimer) to Escherichia coli and Bacillus subtilis. Appl. Environ. Microbiol. 78(5), 1593-1595 (2012).

.. First description of simple cloning by prolonged overlap extension (POE)-PCR to generate plasmids with inserts of 0.2-11 kb. The influence of the elongation time on the POE-PCR product is thoroughly investigated.

2. You C, Percival Zhang YH. Easy preparation of a large-size random gene mutagenesis library in Escherichia coli. Anal. Biochem. 428(1), 7-12 (2012).

3. Cao P, Wang L, Zhou G, Wang Y, Chen Y. Rapid assembly of multiple DNA fragments through direct transformation of PCR products into E. coli and Lactobacillus. Plasmid 76, 40-46 (2014).

4. Cheng F, Xu J-M, Xiang C, Liu Z-Q, Zhao L-Q, Zheng Y-G. Simple-MSSM: a simple and efficient method for simultaneous multi-site saturation mutagenesis. Biotechnol. Lett. 39(4), 567-575 (2017).

5. Bachman J. Site-directed mutagenesis. Methods Enzymol. 529, 241-248 (2013).

6. You C, Zhang YH. Simple cloning and DNA assembly in Escherichia coli by prolonged overlap extension PCR. Methods Mol. Biol. 1116, 183-192 (2014).

- Protocol and troubleshooting for POE-PCR.

7. Zhong C, You C, Wei P, Zhang YH. Simple cloning by prolonged overlap extension-PCR with application to the preparation of large-size random gene mutagenesis library in Escherichia coli. Methods Mol. Biol. 1472, 49-61 (2017).

- Protocol and troubleshooting for POE-PCR.

8. Quadros RM, Miura H, Harms DW et al. Easi-CRISPR: a robust method for one-step generation of mice carrying conditional and insertion alleles using long ssDNA donors and CRISPR ribonucleoproteins. Genome Biol. 18(1), 92 (2017). 